ISSN 1660-3397

www.mdpi.com/journal/marinedrugs

\title{
Article
}

\section{Toward the Synthesis and Biological Screening of a Cyclotetrapeptide from Marine Bacteria}

\section{Rajiv Dahiya * and Hemendra Gautam}

Department of Pharmaceutical Chemistry, NRI Institute of Pharmacy, Bhopal 462 021, Madhya Pradesh, India; E-Mail: hemendra_gautam2002@yahoo.com

* Author to whom correspondence should be addressed; E-Mail: drrajivdahiya@ rediffmail.com or drrajivdahiya@yahoo.com; Tel.: +91-96302-29885 or +91-755-4285308.

Received: 11 November 2010; in revised form: 16 December 2010 / Accepted: 23 December 2010 / Published: 30 December 2010

\begin{abstract}
The first synthesis of a naturally occurring tetrapeptide cyclo-(isoleucyl-prolylleucyl-alanyl) has been achieved using a solution-phase technique via coupling of dipeptide segments Boc-L-Pro-L-Leu-OH and L-Ala-L-Ile-OMe. Deprotection of the linear tetrapeptide unit and its subsequent cyclization gave a cyclopeptide, identical in all aspects to the naturally occurring compound. Bioactivity results indicated the antifungal and antihelmintic potential of the synthesized peptide against pathogenic dermatophytes and earthworms.
\end{abstract}

Keywords: natural product synthesis; marine bacteria; cyclic tetrapeptide; biological activity; Halisarca ectofibrosa; Diginea sp.

\section{Introduction}

Naturally occurring cyclic peptides have generated much interest in recent years due to their intriguing chemical structures and potent biological activity. They show therapeutic potential as a result of greater resistance to in vivo enzymatic degradation as well as greater bioavailability than non-cyclic analogs. Cyclooligopeptides, especially medium ring-sized peptides bearing aliphatic amino acid units, have been reported from diverse marine sources, including marine microorganisms [1-5]. These cyclic congeners derived from marine microorganisms exhibit a range of pharmacological activities, including antimicrobial activity [6], cytotoxicity [7,8], anti-dinoflagellate activity [9] and inhibitory activity against enzyme sortase B [10]. A natural cyclotetrapeptide cyclo-(isoleucyl-prolylleucyl-alanyl) has been isolated from the marine bacteria Pseudomonas sp. and Pseudoalteromonas sp., 
associated with the seaweed Diginea sp. and the sponge Halisarca ectofibrosa and the peptide's structure was elucidated on basis of LC-MS/2D NMR data [11].

Keeping in view the wide array of bioactivities possessed by natural cyclooligopeptides [12,13] and in continuation of our previous investigations on peptides [14-22], an attempt was made toward the synthesis of a natural cyclic tetrapeptide (4) employing a solution-phase synthesis method. In addition, the synthesized product was further subjected to anthelmintic and antimicrobial activity studies.

\section{Results and Discussion}

The title compound 4 was synthesized by the method shown in Scheme 1. In order to carry out the synthesis of cyclo-(isoleucyl-prolyl-leucyl-alanyl), the molecule was split into two dipeptide units: Boc-L-Pro-L-Leu-OMe (1) and Boc-L-Ala-L-Ile-OMe (2). The dipeptides were prepared by coupling Boc-amino acids viz. Boc-L-Pro-OH and Boc-L-Ala-OH with respective amino acid methyl ester hydrochlorides like L-Leu-OMe.HCl and L-Ile-OMe.HCl using 1-ethyl-3-(3-dimethylaminopropyl)carbodiimide hydrochloride (EDC.HCl) as coupling agent and pyridine as base [23]. The ester group of dipeptide 1 was removed with lithium hydroxide (LiOH) and deprotected peptide 1a was coupled with dipeptide 2a deprotected at the amino terminal using trifluoroacetic acid (TFA), to get the linear tetrapeptide unit Boc-L-Pro-L-Leu-L-Ala-L-Ile-OMe (3). Finally, cyclization of the linear tetrapeptide $\mathbf{3}$ was done by the pentafluorophenyl ester method to obtain the cyclooligopeptide cyclo-(isoleucyl-prolyl-leucyl-alanyl) (4). Structures of newly synthesized cyclopeptide and intermediate peptides were elucidated by spectral/elemental analysis (Tables 1 and 2).

Scheme 1. Synthesis of cyclotetrapeptide 4.

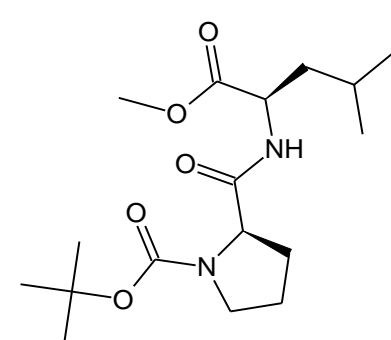

1

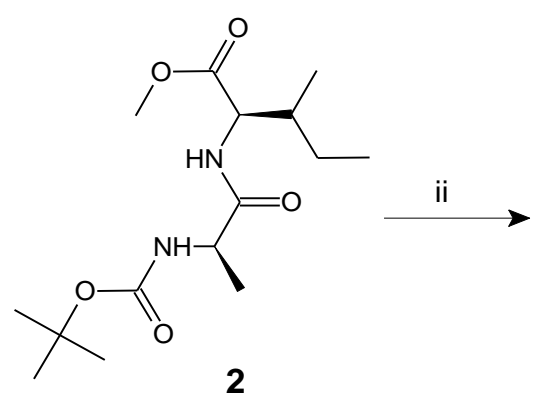<smiles>CC(C)C[C@H](NC(=O)C1CCCN1C(=O)OC(C)(C)C)C(=O)O</smiles>

$1 \mathbf{a}$<smiles>CCC(C)[C@H](NC(=O)[C@H](C)N)C(=O)OC</smiles>

2a

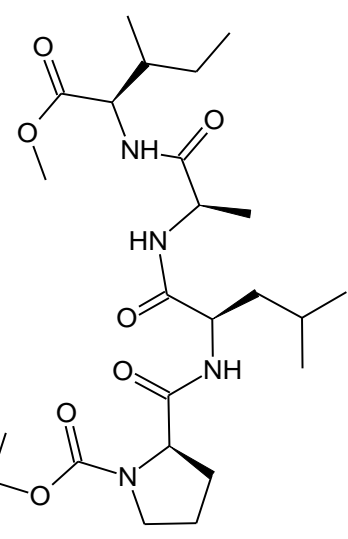

3 
Scheme 1. Cont.

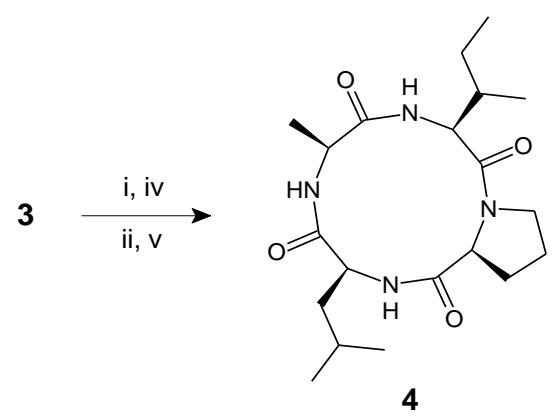

$\mathrm{i}=\mathrm{LiOH}, \mathrm{THF}: \mathrm{H}_{2} \mathrm{O}$ (1:1), RT, 1 h; ii = TFA, $\mathrm{CHCl}_{3}, \mathrm{RT}, 1 \mathrm{~h}$; iii = EDC.HCl, HOBt, pyridine, DCM/DMF, RT, 24-36 h; iv = EDC. $\mathrm{HCl}$, pfp, $\mathrm{RT}, 12 \mathrm{~h} ; \mathrm{v}=\mathrm{TEA} / \mathrm{NMM}, \mathrm{CHCl}_{3}, 7$ days, $0^{\circ} \mathrm{C}$.

Table 1. Physical characterization data for 1-4.

\begin{tabular}{|c|c|c|c|c|c|c|c|c|c|}
\hline \multirow[t]{2}{*}{ Compound } & \multirow{2}{*}{$\begin{array}{c}\text { Physical } \\
\text { state }\end{array}$} & \multirow{2}{*}{$\begin{array}{l}\text { M.p. } \\
\left({ }^{\circ} \mathbf{C}\right)\end{array}$} & \multirow{2}{*}{$\begin{array}{c}\alpha_{[D]}{ }^{a} \\
\left(^{\circ}\right)\end{array}$} & \multirow{2}{*}{$\begin{array}{l}\text { Yield } \\
(\%)\end{array}$} & \multirow[t]{2}{*}{$\mathbf{R}_{\mathbf{f}}^{b}$} & \multirow{2}{*}{$\begin{array}{c}\text { Mol. } \\
\text { Formula } \\
\left(\mathbf{M}_{\mathbf{r}}\right) \\
\end{array}$} & \multicolumn{3}{|c|}{$\begin{array}{l}\text { Elemental analysis } \\
\text { Calcd./found (\%) }\end{array}$} \\
\hline & & & & & & & C & $\mathbf{H}$ & $\mathbf{N}$ \\
\hline 1 & $\begin{array}{l}\text { Viscous } \\
\text { mass }\end{array}$ & - & $+71.4^{1}$ & 87 & 0.69 & $\begin{array}{c}\mathrm{C}_{17} \mathrm{H}_{30} \mathrm{~N}_{2} \mathrm{O}_{5} \\
(342)\end{array}$ & $\begin{array}{l}59.63 \\
59.62\end{array}$ & $\begin{array}{l}8.83 \\
8.85\end{array}$ & $\begin{array}{l}8.18 \\
8.21\end{array}$ \\
\hline $1 \mathbf{a}$ & $\begin{array}{l}\text { White } \\
\text { solid }\end{array}$ & $79-80$ & +41.6 & 72 & 0.53 & $\begin{array}{c}\mathrm{C}_{16} \mathrm{H}_{28} \mathrm{~N}_{2} \mathrm{O}_{5} \\
(328)\end{array}$ & $\begin{array}{l}58.52 \\
58.49\end{array}$ & $\begin{array}{l}8.59 \\
8.62\end{array}$ & $\begin{array}{l}8.53 \\
8.55\end{array}$ \\
\hline 2 & $\begin{array}{l}\text { Viscous } \\
\text { mass }\end{array}$ & - & -121.8 & 93 & 0.87 & $\begin{array}{c}\mathrm{C}_{15} \mathrm{H}_{28} \mathrm{~N}_{2} \mathrm{O}_{5} \\
(316)\end{array}$ & $\begin{array}{l}56.94 \\
56.95\end{array}$ & $\begin{array}{l}8.92 \\
8.94\end{array}$ & $\begin{array}{l}8.85 \\
8.83\end{array}$ \\
\hline $2 \mathbf{a}$ & $\begin{array}{l}\text { Semisolid } \\
\text { mass }\end{array}$ & - & -89.2 & 78 & 0.66 & $\begin{array}{c}\mathrm{C}_{10} \mathrm{H}_{20} \mathrm{~N}_{2} \mathrm{O}_{3} \\
(216)\end{array}$ & $\begin{array}{l}55.53 \\
55.52\end{array}$ & $\begin{array}{l}9.32 \\
9.35\end{array}$ & $\begin{array}{l}12.95 \\
12.97\end{array}$ \\
\hline 3 & $\begin{array}{l}\text { Semisolid } \\
\text { mass }\end{array}$ & - & $-55.1^{2}$ & 91 & 0.81 & $\begin{array}{c}\mathrm{C}_{26} \mathrm{H}_{46} \mathrm{~N}_{4} \mathrm{O}_{7} \\
(526)\end{array}$ & $\begin{array}{l}59.29 \\
59.26\end{array}$ & $\begin{array}{l}8.80 \\
8.79\end{array}$ & $\begin{array}{l}10.64 \\
10.66\end{array}$ \\
\hline 4 & $\begin{array}{l}\text { White } \\
\text { solid }\end{array}$ & 198 (d) & $\begin{array}{l}-12.9^{3} \\
(-13.0)\end{array}$ & 74 & $0.62 *$ & $\begin{array}{c}\mathrm{C}_{20} \mathrm{H}_{34} \mathrm{~N}_{4} \mathrm{O}_{4} \\
(394)\end{array}$ & $\begin{array}{l}60.89 \\
60.91\end{array}$ & $\begin{array}{l}8.69 \\
8.70\end{array}$ & $\begin{array}{l}14.20 \\
14.18\end{array}$ \\
\hline
\end{tabular}

${ }^{\mathrm{a}} c, 0.5$ in $\mathrm{MeOH} ;{ }^{1} c, 0.25$ in $\mathrm{MeOH} ;{ }^{2} c, 0.15$ in $\mathrm{MeOH} ;{ }^{3} c, 0.05$ in $\mathrm{MeOH} ;{ }^{\mathrm{b}}\left(\mathrm{CHCl}_{3}: \mathrm{MeOH} / 7: 3\right)$;

$*\left(\mathrm{CHCl}_{3}: \mathrm{MeOH} / 9: 1\right)$.

Table 2. Spectral data for $1-4$.

Compound IR $\left(\mathrm{CHCl}_{3} / \mathrm{KBr}, v \mathrm{~cm}^{-1}\right),{ }^{1} \mathrm{H} /{ }^{13} \mathrm{C} \mathrm{NMR}\left(\mathrm{CDCl}_{3}, \delta\right.$ ppm), ESIMS/MS (rel. int., $\left.m / z\right)$ 3128, 3123 (N-H str, amide), 2998-2989 (C-H str, $\mathrm{CH}_{2}$, Pro), 2966, 2928 (C-H str, asym, $\mathrm{CH}_{3}$ and $\left.\mathrm{CH}_{2}\right), 1748(\mathrm{C}=\mathrm{O}$ str, ester $), 1675,1643(\mathrm{C}=\mathrm{O}$ str, tert and sec amide), 1539 ( $\mathrm{N}-\mathrm{H}$ def, sec amide), 1391, 1377 (C-H def, tert-Butyl), 1384, 1369

1 (C-H def, iso-propyl), 1267 (C-O str, ester)

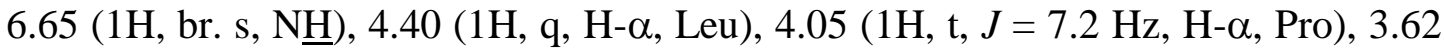

$\left(3 \mathrm{H}, \mathrm{s}, \mathrm{OC}_{3}\right), 3.22$ ( $2 \mathrm{H}, \mathrm{t}, J=7.2 \mathrm{~Hz}, \mathrm{H}-\delta$, Pro), 2.58 (2H, q, H- $\beta$, Pro), 1.96-1.88

(2H, m, H- $\gamma$, Pro), 1.47 (9H, s, tert-Butyl), 1.45-1.36 (3H, m, H- $\beta$ and $\mathrm{H}-\gamma, \mathrm{Leu}), 0.94$ $(6 \mathrm{H}, \mathrm{d}, J=6.35 \mathrm{~Hz}, \mathrm{H}-\delta, \mathrm{Leu})$ 
Table 2. Cont.

3297-2478 (m/br, OH str, COOH), 3125, 3122 (N-H str, amide), 2999-2992 (C-H str, $\mathrm{CH}_{2}$, Pro), 2968, 2929 (C-H str, asym, $\mathrm{CH}_{3}$ and $\mathrm{CH}_{2}$ ), 1711 (s, C=O str, $\mathrm{COOH}$ ), 1678, 1642 ( $\mathrm{C}=\mathrm{O}$ str, tert and sec amide), $1536(\mathrm{~N}-\mathrm{H}$ def, sec amide), 1393, 1375 (C-H def, tert-Butyl), 1385, 1368 (C-H def, iso-propyl)

1a $12.52(1 \mathrm{H}, \mathrm{s}, \mathrm{O} \underline{\mathrm{H}}, \mathrm{COOH}), 6.73(1 \mathrm{H}$, br. s, N$), 4.47(1 \mathrm{H}, \mathrm{q}, \mathrm{H}-\alpha, \mathrm{Leu}), 3.86(1 \mathrm{H}, \mathrm{t}$, $J=7.2 \mathrm{~Hz}, \mathrm{H}-\alpha$, Pro), $3.21(2 \mathrm{H}, \mathrm{t}, J=7.15 \mathrm{~Hz}, \mathrm{H}-\delta$, Pro), 2.55 ( $2 \mathrm{H}, \mathrm{q}, \mathrm{H}-\beta$, Pro), 1.95-1.87 (3H, m, H- $\gamma$, Pro and Leu), $1.56(2 \mathrm{H}, \mathrm{t}, \mathrm{H}-\beta, \mathrm{Leu}), 1.49$ (9H, s, tert-Butyl), $0.95(6 \mathrm{H}, \mathrm{d}, J=6.4 \mathrm{~Hz}, \mathrm{H}-\delta$, Leu $)$

3502, 3396 (N-H str, sec amine), 3132, 3127 (N-H str, amide), 2965, 2928 (C-H str, asym, $\mathrm{CH}_{3}$ and $\left.\mathrm{CH}_{2}\right), 2874\left(\mathrm{C}-\mathrm{H}\right.$ str, sym, $\left.\mathrm{CH}_{3}\right), 1747(\mathrm{C}=\mathrm{O}$ str, ester $), 1646(\mathrm{C}=\mathrm{O}$ str, sec amide), 1535 (N-H def, sec amide), 1269 (C-O str, ester), 1159 (C-N str, sec amine)

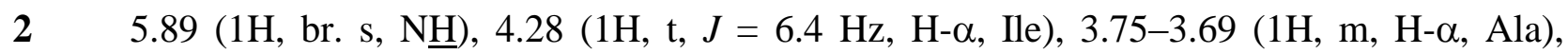
$3.51\left(3 \mathrm{H}, \mathrm{s}, \mathrm{OC}_{3}\right), 2.03-1.95(1 \mathrm{H}, \mathrm{m}, \mathrm{H}-\beta, \mathrm{Ile}), 1.70-1.62(2 \mathrm{H}, \mathrm{m}, \mathrm{H}-\gamma, \mathrm{Ile}), 1.46$ (2H, br. s, $\left.\mathrm{NH}_{2}\right), 1.15(3 \mathrm{H}, \mathrm{d}, J=7.25 \mathrm{~Hz}, \mathrm{H}-\beta$, Ala), $0.94(3 \mathrm{H}, \mathrm{t}, J=7.2 \mathrm{~Hz}, \mathrm{H}-\delta, \mathrm{Ile}), 0.86(3 \mathrm{H}, \mathrm{d}$, $\left.J=6.4 \mathrm{~Hz}, \mathrm{H}-\gamma^{\prime}, \mathrm{Ile}\right)$

3129-3122 (N-H str, amide), 2999-2993 (C-H str, $\mathrm{CH}_{2}$, Pro), 2968, 2929, 2925 (C-H str, asym, $\mathrm{CH}_{3}$ and $\left.\mathrm{CH}_{2}\right), 2878-2873\left(\mathrm{C}-\mathrm{H}\right.$ str, sym, $\left.\mathrm{CH}_{3}\right), 1745(\mathrm{C}=\mathrm{O}$ str, ester), 1676, 1646-1641 (C=O str, tert and sec amide), 1538, 1535 ( $\mathrm{N}-\mathrm{H}$ def, sec amide), 1392, 1375 (C-H def, tert-Butyl), 1386, 1368 (C-H def, iso-propyl), 1272 (C-O str, ester)

$8.48(1 \mathrm{H}$, br. s, $\mathrm{NH}), 7.45(1 \mathrm{H}$, br. s, $\underline{\mathrm{H}}), 5.14(1 \mathrm{H}$, br. s, $\mathrm{N} \underline{\mathrm{H}}), 4.52(1 \mathrm{H}, \mathrm{q}, \mathrm{H}-\alpha, \mathrm{Leu})$, $4.25(1 \mathrm{H}, \mathrm{q}, \mathrm{H}-\alpha$, Ala), $4.14(1 \mathrm{H}, \mathrm{t}, J=7.2 \mathrm{~Hz}, \mathrm{H}-\alpha, \mathrm{Pro}), 3.73(1 \mathrm{H}, \mathrm{t}, J=6.35 \mathrm{~Hz}, \mathrm{H}-\alpha$, Ile), $3.49\left(3 \mathrm{H}, \mathrm{s}, \mathrm{OC}_{3}\right), 3.43(2 \mathrm{H}, \mathrm{t}, J=7.25 \mathrm{~Hz}, \mathrm{H}-\delta$, Pro), 2.49 (2H, q, H- $\beta$, Pro), 2.05-1.97 (1H, m, H- $\beta$, Ile), 1.95-1.89 (2H, m, H- $\gamma$, Pro), 1.83-1.62 (4H, m, H- $\beta$, Leu and $\mathrm{H}-\gamma$, Ile), 1.48 (9H, s, tert-Butyl), 1.48-1.43 (1H, m, H- $\gamma, \mathrm{Leu}), 1.29(3 \mathrm{H}, \mathrm{d}, J=7.2 \mathrm{~Hz}$, H- $\beta$, Ala), 0.99 (6H, d, $J=6.4 \mathrm{~Hz}, \mathrm{H}-\delta, \mathrm{Leu}), 0.93$ (3H, t, $J=7.15 \mathrm{~Hz}, \mathrm{H}-\delta, \mathrm{Ile}), 0.89$ (3H, $\mathrm{d}, J=6.45 \mathrm{~Hz}, \mathrm{H}-\gamma^{\prime}$, Ile)

$174.8(\mathrm{C}=\mathrm{O}, \mathrm{Leu}), 172.9,172.4$ (2C, $\mathrm{C}=\mathrm{O}$, Pro and Ile), 169.8 ( $\mathrm{C}=\mathrm{O}, \mathrm{Ala}), 156.2(\mathrm{C}=\mathrm{O}, \mathrm{Boc})$, 79.8 (C- $\alpha$, tert-Butyl), 59.7 (C- $\alpha$, Pro), 58.5 (C- $\alpha$, Ile), $54.7\left(\mathrm{O}_{-} H_{3}\right), 51.3$ (C- $\alpha$, Ala), 49.7 (C- $\alpha$, Leu), 46.9 (C- $\delta$, Pro), 37.6, 37.1 (2C, C- $\beta$, Ile and Leu), 28.9 (C- $\beta$, Pro), 28.2 (3C, C- $\beta$, tert-Butyl), 24.2, 23.9 (2C, C- $\gamma$, Ile and Leu), 23.7 (C- $\gamma$, Pro), 22.3 (2C, C- $\delta$, Leu), 17.9 (C- $\beta$, Ala), 15.1 (C- $\gamma^{\prime}$, Ile), 9.5 (C- $\delta$, Ile)

3128, 3123, 3119 (N-H str, amide), 2998, 2995-2992 (C-H str, $\mathrm{CH}_{2}$, Pro), 2969, 2928-2924 (C-H str, asym, $\mathrm{CH}_{3}$ and $\left.\mathrm{CH}_{2}\right), 2879,2875\left(\mathrm{C}-\mathrm{H}\right.$ str, sym, $\left.\mathrm{CH}_{3}\right), 1675$, 1648-1643 ( $\mathrm{C}=\mathrm{O}$ str, tert and sec amide), 1539-1536 ( $\mathrm{N}-\mathrm{H}$ def, sec amide), 1385, 1369 (C-H def, iso-propyl)

$9.37(1 \mathrm{H}$, br. s, $\mathrm{N} \underline{\mathrm{H}}), 9.31(1 \mathrm{H}$, br. s, $\mathrm{N} \underline{\mathrm{H}}), 7.76(1 \mathrm{H}$, br. s, $\underline{\mathrm{H}}), 4.26(1 \mathrm{H}, \mathrm{t}, J=7.15 \mathrm{~Hz}$, H- $\alpha$, Pro), 3.99 (1H, q, H- $\alpha$, Ala), $3.95(1 \mathrm{H}, \mathrm{q}, \mathrm{H}-\alpha, \mathrm{Leu}), 3.61(1 \mathrm{H}, \mathrm{t}, J=6.4 \mathrm{~Hz}, \mathrm{H}-\alpha$, Ile), 3.52 (2H, t, $J=7.3 \mathrm{~Hz}, \mathrm{H}-\delta$, Pro), 2.35 (2H, q, H- $\beta$, Pro), 1.96-1.83 (2H, m, H- $\gamma$, Pro), 1.89-1.83 (1H, m, H- $\gamma$, Leu), 1.81-1.76 (1H, m, H- $\beta$, Ile), 1.73-1.64 (2H, m, H- $\beta$, Leu), 1.59-1.53 (2H, m, H- $\gamma$, Ile), $1.45(3 \mathrm{H}, \mathrm{d}, J=7.25 \mathrm{~Hz}, \mathrm{H}-\beta$, Ala $), 0.98(6 \mathrm{H}, \mathrm{d}, J=6.35 \mathrm{~Hz}$, $\mathrm{H}-\delta$, Leu $), 0.95\left(3 \mathrm{H}, \mathrm{d}, J=6.45 \mathrm{~Hz}, \mathrm{H}-\gamma^{\prime}\right.$, Ile $), 0.89$ (3H, t, $J=7.2 \mathrm{~Hz}, \mathrm{H}-\delta$, Ile) 171.1 (C=O, Leu), 170.9 (C=O, Ala), 170.5, 168.1 (2C, C=O, Pro and Ile), 63.3 (C- $\alpha$, Ile), 57.5 (C- $\alpha$, Pro), 54.1 (C- $\alpha$, Leu), 49.9 (C- $\alpha$, Ala), 46.5 (C- $\delta$, Pro), 43.8, 39.9 (2C, C- $\beta$, Leu and Ile), 29.9 (C- $\beta$, Pro), 24.8, 24.2 (2C, C- $\gamma$, Ile and Leu), 22.0 (2C, C- $\delta$, Leu), 21.3 (C- $\gamma$, Pro), 19.2 (C- $\beta$, Ala), 15.4 (C- $\gamma^{\prime}$, Ile), 9.8 (C- $\delta$, Ile) 
Table 2. Cont.

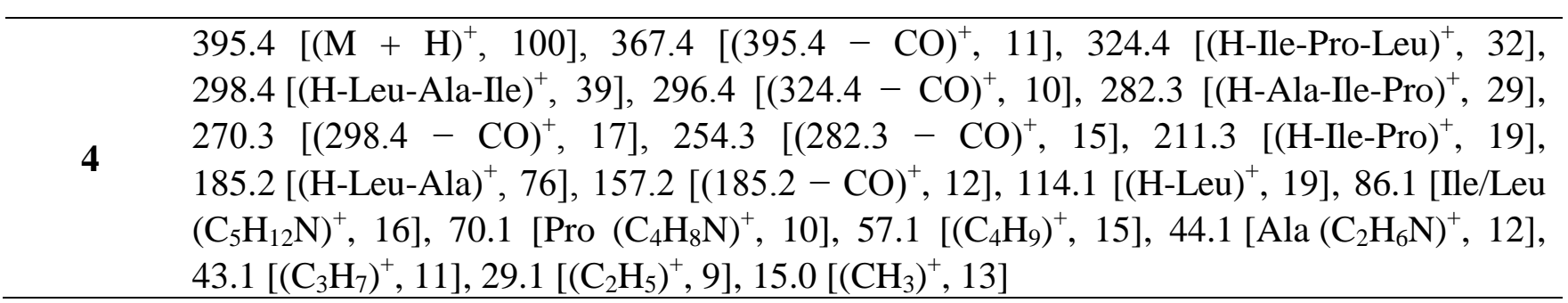

Synthesis of the natural cyclotetrapeptide 4 was completed successfully from the linear precursor and $N$-methylmorpholine (NMM) was proven to be an effective base for cyclizing linear tetrapeptide segment. Disappearance of absorption bands at $1745,1272 \mathrm{~cm}^{-1}$ and $1392,1375 \mathrm{~cm}^{-1}\left(\mathrm{C}=\mathrm{O}_{\text {str }}\right.$ and $\mathrm{C}-\mathrm{O}_{\text {str }}$, methyl ester group and $\mathrm{C}-\mathrm{H}_{\text {bend }}$, tert-Butyl group) in FT-IR spectrum of $\mathbf{4}$ clearly indicated cyclization of the linear tetrapeptide unit. This fact was further supported by the disappearance in the ${ }^{1} \mathrm{H}$ NMR spectrum of 4 of two singlets at $\delta 1.48$ and $\delta 3.49$ corresponding to protons of tert-Butyl and methyl ester groups of 3. Four signals between $\delta 4.26-3.61$ in the proton spectrum of 4 suggested a peptidic structure for the synthesized product, with these signals being attributable to the $\alpha$-protons of all amino acid units. The ${ }^{1} \mathrm{H}$ NMR spectrum of the cyclized product showed the presence of three broad singlets between $\delta 9.37-7.76$ corresponding to the imino protons of the isoleucine, leucine and alanine moieties, the remaining amino acid being the proline unit, indicating similarity of the structure of the newly synthesized cyclotetrapeptide with the natural molecule. The NMR data of the synthetic cyclotetrapeptide are identical with those of the natural product within the error range of $\delta 0.06\left({ }^{1} \mathrm{H}\right)$ and $1\left({ }^{13} \mathrm{C}\right)$, respectively. Moreover, ${ }^{1} \mathrm{H} /{ }^{13} \mathrm{C}$ NMR spectra of the cyclized product 4 showed characteristic peaks confirming the presence of all the 34 protons and 20 carbon atoms. Presence of pseudomolecular ion peak at $\mathrm{m} / z 395.4$ corresponding to the molecular formula $\mathrm{C}_{20} \mathrm{H}_{34} \mathrm{~N}_{4} \mathrm{O}_{4}$ in the mass spectrum of 4, along with other fragment ion peaks resulting from cleavage at "Leu-Pro", "Ile-Ala" and "Ala-Leu" amide bonds, showed the exact sequence of attachment of all the four amino acid units in the chain. In addition, elemental data analysis of $\mathbf{4}$ afforded values $( \pm 0.02)$ strictly in accordance with the molecular composition.

The newly synthesized cyclooligopeptide $\mathbf{4}$ exhibited potent anthelmintic activity at a concentration of $2 \mathrm{mg} / \mathrm{mL}$ in tween $80(0.5 \%)$ and distilled water. Comparison of the anthelmintic activity data revealed that the cyclopeptide $\mathbf{4}$ displayed greater activity than it's corresponding linear precursor $\mathbf{3}$ and the standard drug, mebendazole, against all three earthworm species M. konkanensis, P. corethruses and E. eugeniea (Table 3).

Analysis of the antimicrobial activity data indicated that cyclopeptide 4, compared to the standard drug gatifloxacin, displayed moderate antibacterial activity against the Gram-negative bacteria $P$. aeruginosa and $K$. pneumoniae, and antifungal activity against pathogenic $C$. albicans with minimum inhibitory concentration (MIC) values of $6 \mu \mathrm{g} / \mathrm{mL}$. Moreover, 4 displayed potent bioactivity against dermatophytes $M$. audouinii and T. mentagrophytes with MIC values of $6 \mu \mathrm{g} / \mathrm{mL}$. However, 4 displayed no bioactivity against either Gram-positive bacteria or against the fungus A. niger (Table 4). 
Table 3. Anthelmintic screening data for 3 and 4.

\begin{tabular}{lllllll}
\hline & \multicolumn{6}{c}{ Earthworm species } \\
\cline { 2 - 7 } Compound & \multicolumn{2}{c}{ M. konk. } & \multicolumn{1}{c}{ P. core. } \\
\cline { 2 - 7 } & $\begin{array}{llllll}\text { Mean } \\
\text { paralyzing } \\
\text { time (min) }\end{array}$ & $\begin{array}{l}\text { Mean } \\
\text { death } \\
\text { time (min) }\end{array}$ & $\begin{array}{l}\text { Mean } \\
\text { paralyzing } \\
\text { time (min) }\end{array}$ & $\begin{array}{l}\text { Mean } \\
\text { death } \\
\text { time (min) }\end{array}$ & $\begin{array}{l}\text { Mean } \\
\text { paralyzing } \\
\text { time (min) }\end{array}$ & $\begin{array}{l}\text { Mean } \\
\text { death } \\
\text { time (min) }\end{array}$ \\
\hline $\mathbf{3}^{\dagger}$ & $14.25 \pm 0.42$ & $22.57 \pm 0.36$ & $18.11 \pm 0.26$ & $29.47 \pm 0.14$ & $14.12 \pm 0.23$ & $24.54 \pm 0.12$ \\
$\mathbf{4}^{\dagger}$ & $9.28 \pm 0.20$ & $18.27 \pm 0.17$ & $12.44 \pm 0.19$ & $23.55 \pm 0.27$ & $12.40 \pm 0.13$ & $22.05 \pm 0.37$ \\
Control $^{\#}$ & - & - & - & - & - & - \\
Mebendazole $^{\dagger}$ & $13.85 \pm 0.64$ & $22.85 \pm 0.53$ & $17.82 \pm 0.43$ & $29.60 \pm 0.22$ & $13.54 \pm 0.45$ & $24.05 \pm 0.62$ \\
\hline
\end{tabular}

M. konk.: Megascoplex konkanensis; P. core.: Pontoscotex corethruses; E. euge.: Eudrilus eugeniea;

${ }^{\dagger}$ Conc. $=2 \mathrm{mg} / \mathrm{mL} ;{ }^{\ddagger}$ Data are given as mean \pm S.D. $(n=3) ;{ }^{*}$ Tween $80(0.5 \%)$ in distilled water.

Table 4. Antimicrobial screening data for 3 and 4.

\begin{tabular}{|c|c|c|c|c|c|c|c|c|}
\hline \multirow{3}{*}{ Compound } & \multicolumn{8}{|c|}{ Diameter of zone of inhibition $(\mathbf{m m})$} \\
\hline & \multicolumn{4}{|c|}{ Bacterial strains } & \multicolumn{4}{|c|}{ Fungal strains } \\
\hline & B. sub. & S. aur. & P. aeru. & K. pneu. & C. alb. & M. audo. & A. niger & T. menta. \\
\hline 3 & - & - & $13(6)^{\dagger}$ & $16(6)$ & $12(6)$ & $18(6)$ & - & $19(6)$ \\
\hline 4 & - & - & $18(6)$ & $20(6)$ & $15(6)$ & $23(6)$ & - & $25(6)$ \\
\hline Control * & - & - & - & - & - & - & - & - \\
\hline Gatifloxacin & $18(12.5)$ & $28(6)$ & $22(6)$ & $25(6)$ & - & - & - & - \\
\hline Griseofulvin & - & - & - & - & $20(6)$ & $17(6)$ & $18(12.5)$ & $20(6)$ \\
\hline
\end{tabular}

\section{Experimental Section}

Melting points were determined in open capillaries and are uncorrected. IR spectra were recorded on a Shimadzu 8700 FTIR spectrophotometer and ${ }^{1} \mathrm{H} /{ }^{13} \mathrm{C}$ NMR spectra were recorded on a Bruker AC NMR spectrometer (300 MHz) using deuterated chloroform as solvent and TMS as internal standard. The mass spectra were recorded on a JMS-DX 303 Mass spectrometer operating at $70 \mathrm{eV}$ by ESIMS/MS. Optical rotation of synthesized peptide derivatives was measured on an automatic polarimeter at $25{ }^{\circ} \mathrm{C}$ using a sodium lamp. Elemental analysis of all compounds was performed on a Vario EL III elemental analyzer. Purity of all synthesized compounds was checked by TLC on precoated silica gel $\mathrm{G}$ plates.

\subsection{Extraction and Isolation of Natural Cyclic Tetrapeptide}

As reported earlier, a bacterial strain identified as a Pseudomonas sp. by $16 \mathrm{~S}$ rRNA analysis was obtained from the Japanese seaweed Diginea sp., an alga which has a symbiotic relationship with dinoflagellates such as Amphidinium sp. The colonies inhibited the growth of other marine bacteria when grown on seawater based agar medium. Purification by $\mathrm{SiO}_{2}$ column chromatography and reversed-phase $\mathrm{HPLC}$ of the $\mathrm{CHCl}_{3}-\mathrm{MeOH}$ soluble fractions of the culture supernatant gave 
peptide-containing fractions that were analyzed by ${ }^{1} \mathrm{H}$ NMR and by LC-MS. Extensive 2D NMR analysis of the individual cyclopeptide components confirmed the isolation of the novel cyclotetrapeptide cyclo-(isoleucyl-prolyl-leucyl-alanyl) in addition to other previously characterized peptides [11].

The culture broth $(1.5 \mathrm{~L})$ of a bacterial strain No. 27 (Pseudomonas sp.) was centrifuged, and the bacterial cells were extracted with $\mathrm{CHCl}_{3} / \mathrm{MeOH}(1: 1,500 \mathrm{~mL})$. The combined extracts were concentrated, and the residue was partitioned with EtOAc and water. The EtOAc layer (152 mg) showed potent antimicrobial activity against an orange-colored unidentified bacterium associated with the same host (Diginea sp.). After further separation by Si gel chromatography and elution using a solvent gradient of hexanes $/ \mathrm{CHCl}_{3} / \mathrm{EtOAc} / \mathrm{MeOH}$, the fraction eluted in EtOAc/MeOH (1:1) was subjected to reverse phase HPLC using a $\mathrm{MeOH} / \mathrm{H}_{2} \mathrm{O}$ gradient from 50 to $100 \% \mathrm{MeOH}$ and UV detection at $215 \mathrm{~nm}$ to give the desired cyclic tetrapeptide $(2.0 \mathrm{mg})$.

\subsection{General Procedure for the Preparation of Linear Dipeptide Fragments}

L-Amino acid methyl ester hydrochloride $(0.01 \mathrm{~mol})$ was dissolved in $\mathrm{CH}_{2} \mathrm{Cl}_{2}(20 \mathrm{~mL})$. Pyridine $(1.61 \mathrm{~mL}, 0.021 \mathrm{~mol})$ was added to the mixture at $0{ }^{\circ} \mathrm{C}$ and stirred for $15 \mathrm{~min}$. Boc-L-amino acid $(0.01 \mathrm{~mol})$ was dissolved in $\mathrm{CH}_{2} \mathrm{Cl}_{2}(20 \mathrm{~mL})$ followed by addition of $\mathrm{EDC} . \mathrm{HCl}(1.92 \mathrm{~g}, 0.01 \mathrm{~mol})$ and HOBt (1.34 g, $0.01 \mathrm{~mol})$. The resulting mixture was added to the above solution with constant shaking and stirring was continued for $24 \mathrm{~h}$. The reaction mixture was filtered and the residue was washed with $\mathrm{CH}_{2} \mathrm{Cl}_{2}(30 \mathrm{~mL})$ and added to the filtrate. The filtrate was washed with $5 \% \mathrm{NaHCO}_{3}$ and saturated $\mathrm{NaCl}$ solutions. The organic layer was dried over anhydrous $\mathrm{Na}_{2} \mathrm{SO}_{4}$, filtered and evaporated in vacuum. The crude product was recrystallized from a mixture of chloroform and petroleum ether (b.p. $40-60{ }^{\circ} \mathrm{C}$ ) followed by cooling at $0{ }^{\circ} \mathrm{C}$ to get the title compounds.

\subsection{Procedure for the Synthesis of Linear Tetrapeptide Unit and Its Cyclization}

L-Alanyl-L-isoleucine methyl ester 2a $(2.16 \mathrm{~g}, 0.01 \mathrm{~mol})$ was dissolved in DMF (25 mL) and pyridine $(0.021 \mathrm{~mol})$ was added to the above solution in proportions. Finally, the reaction mixture was stirred for 30 minutes, while maintaining the temperature between $0-5{ }^{\circ} \mathrm{C}$. Boc-L-prolyl-L-leucine 1a (3.28 g, $0.01 \mathrm{~mol})$ was dissolved in DMF (35 mL) and EDC.HCl (1.92 g, $0.01 \mathrm{~mol})$ and $\mathrm{HOBt}(1.34 \mathrm{~g}$, $0.01 \mathrm{~mol}$ ) were added in proportions while stirring. Stirring was first done for $1 \mathrm{~h}$ at $0-5^{\circ} \mathrm{C}$ and then further for $24 \mathrm{~h}$ at room temperature (RT). After the completion of the reaction, the reaction mixture was diluted with an equal amount of water. The precipitated solid was filtered, washed with water and recrystallized from a mixture of chloroform and petroleum ether (b.p. $40-60{ }^{\circ} \mathrm{C}$ ), followed by cooling at $0{ }^{\circ} \mathrm{C}$ to get Boc-L-prolyl-L-leucyl-L-alanyl-L-isoleucine methyl ester $\mathbf{3}$. The linear tetrapeptide unit $\mathbf{3}$ $(2.63 \mathrm{~g}, 0.005 \mathrm{~mol})$ was deprotected at the carboxyl terminal using lithium hydroxide ( $\mathrm{LiOH}, 0.18 \mathrm{~g}$, $0.0075 \mathrm{~mol}$ ) to obtain Boc-L-prolyl-L-leucyl-L-alanyl-L-isoleucine-OH. To a solution of the deprotected tetrapeptide $(2.56 \mathrm{~g}, 0.005 \mathrm{~mol})$ in $\mathrm{CHCl}_{3}(50 \mathrm{~mL})$, pentafluorophenol $(1.23 \mathrm{~g}, 0.0067 \mathrm{~mol})$ and EDC. $\mathrm{HCl}(0.96 \mathrm{~g}, 0.005 \mathrm{~mol})$ were added followed by stirring at RT for $12 \mathrm{~h}$. Filtrate of the above reaction mixture was washed with $10 \% \mathrm{NaHCO}_{3}(3 \times 20 \mathrm{~mL})$ and $5 \% \mathrm{HCl}(2 \times 20 \mathrm{~mL})$ solutions to obtain corresponding pentafluorophenyl ester Boc-L-prolyl-L-leucyl-L-alanyl-L-isoleucine-Opfp. Boc-group of resulting unit $(2.71 \mathrm{~g}, 0.004 \mathrm{~mol})$ was removed using TFA (0.91 g, $0.008 \mathrm{~mol})$ and deprotected product was dissolved in $\mathrm{CHCl}_{3}(25 \mathrm{~mL})$ and TEA/NMM/pyridine $(2.8 \mathrm{~mL}$ or $2.21 \mathrm{~mL}$ or 
$1.61 \mathrm{~mL}, 0.021 \mathrm{~mol}$ ) was added. Whole contents were then kept at $0{ }^{\circ} \mathrm{C}$ for 7 days. The reaction mixture was washed with $10 \% \mathrm{NaHCO}_{3}(3 \times 25 \mathrm{~mL})$ and $5 \% \mathrm{HCl}(2 \times 25 \mathrm{~mL})$ solutions. The organic layer was dried over anhydrous $\mathrm{Na}_{2} \mathrm{SO}_{4}$ and the crude cyclized compound was recrystallized from $\mathrm{CHCl}_{3} / n$-hexane to obtain the pure cyclic product 4 .

\subsection{Biological Activity Studies}

\subsubsection{Antihelmintic Screening}

Newly synthesized linear and cyclic tetrapeptide $\mathbf{3}$ and $\mathbf{4}$ were subjected to antihelmintic activity studies against three different species of earthworms Megascoplex konkanensis, Pontoscotex corethruses and Eudrilus eugeniea at a concentration of $2 \mathrm{mg} / \mathrm{mL}$ using Garg's method [24]. Tween 80 (0.5\%) in distilled water was used as control and mebendazole was used as a standard drug. Suspensions of samples were prepared by triturating synthesized compounds $(100 \mathrm{mg})$ with tween $80(0.5 \%)$ and distilled water and the resulting mixtures were stirred using a mechanical stirrer for $30 \mathrm{~min}$. The suspensions were diluted to contain $0.2 \%(\mathrm{w} / \mathrm{v})$ of the test samples. Suspension of the reference drug, mebendazole, was prepared with the same concentration in a similar way. Three sets of five earthworms of almost similar sizes ( 2 inches in length) were placed in petri plates of 4 inch diameter containing $50 \mathrm{~mL}$ of suspension of test sample and reference drug at RT. Another set of five earthworms was kept as control in $50 \mathrm{~mL}$ suspension of distilled water and tween $80(0.5 \%)$. The paralyzing and death times were noted and their mean was calculated for triplicate sets. The death time was ascertained by placing the earthworms in warm water $\left(50{ }^{\circ} \mathrm{C}\right)$, which stimulated the movement if the worm was alive. The results of antihelmintic screening are tabulated in Table 3.

\subsubsection{Antimicrobial Screening}

Antibacterial and antifungal screening of synthesized tetrapeptides $\mathbf{3}$ and $\mathbf{4}$ were carried out against the Gram-positive bacteria Bacillus subtilis and Staphylococcus aureus, the Gram-negative bacteria Pseudomonas aeruginosa and Klebsiella pneumoniae, dermatophytes Microsporum audouinii and Trichophyton mentagrophytes, as well as Candida albicans and other fungal strains, including Aspergillus niger at a concentration of $12.5-6 \mu \mathrm{g} / \mathrm{mL}$. A modified Kirby-Bauer disc diffusion method was used for testing [25]. MIC values of test compounds were determined by tube dilution technique. Newly synthesized tetrapeptides were dissolved separately to prepare a stock solution of $1 \mathrm{mg} / \mathrm{mL}$ using DMF. Stock solution was aseptically transferred and suitably diluted with sterile broth medium to contain seven different concentrations of each test compound ranging from $200-3.1 \mu \mathrm{g} / \mathrm{mL}$ in different test tubes. All the tubes were inoculated with one loopful of one of the test bacteria/fungi. The process was repeated with different test bacteria/fungi and different samples. Tubes inoculated with bacterial/fungal cultures were incubated at $37{ }^{\circ} \mathrm{C}$ for $18 \mathrm{~h}$ and $48 \mathrm{~h}$, respectively, and the presence/absence of growth of the bacteria/fungi was observed. From these results, MIC of each test compound was determined against each test bacterium/fungus. A spore suspension in sterile distilled water was prepared from 5 days old culture of the test bacteria/fungi growing on nutrient broth media/sabouraud's broth media. About $20 \mathrm{~mL}$ of the growth medium was transferred into sterilized petri plates and inoculated with $1.5 \mathrm{~mL}$ of the spore suspension (spore concentration: 
$6 \times 10^{4}$ spores $/ \mathrm{mL}$ ). Filter paper disks of $6 \mathrm{~mm}$ diameter and $1 \mathrm{~mm}$ thickness were sterilized by autoclaving at $121^{\circ} \mathrm{C}(15 \mathrm{psig})$ for $15 \mathrm{~min}$. Each petri plate was divided into five equal portions along the diameter to place one disc. Three discs of test sample were placed on three portions together with one disc with reference drug and a disk impregnated with the solvent as negative control. The petri plates inoculated with bacterial cultures were incubated at $37{ }^{\circ} \mathrm{C}$ for $18 \mathrm{~h}$ and those inoculated with fungal cultures were incubated at $37^{\circ} \mathrm{C}$ for $48 \mathrm{~h}$. Gatifloxacin and griseofulvin were used as reference drugs and DMF/DMSO were used as control. Diameters of the zones of inhibition (in mm) were measured and the average diameters for test sample were calculated for triplicate sets. The diameters obtained for the test sample were compared with that produced by the standard drugs. The results of antibacterial and antifungal studies are presented in Table 4.

\section{Conclusions}

First total synthesis of the naturally occurring tetrapeptide cyclo-(isoleucyl-prolyl-leucyl-alanyl) 4 was accomplished with good yield via coupling reactions utilizing carbodiimide chemistry. Pentafluorophenyl ester was proven to be effective for the activation of the acid functionality of the linear tetrapeptide unit. NMM was found to be a good base for intramolecular cyclization of the linear peptide fragment in comparison to TEA and pyridine. Synthesized cyclotetrapeptide 4 displayed potent antihelmintic activity against earthworms $M$. konkanensis, $P$. corethruses and E. eugeniea, along with good antifungal activity against dermatophytes $M$. audouinii and T. mentagrophytes, compared to the reference drugs, mebendazole and griseofulvin. In comparison, Gram-negative bacteria were found to be more sensitive than Gram-positive bacteria toward the newly synthesized peptide. On passing toxicity tests, the newly synthesized cyclooligopeptide $\mathbf{4}$ may prove to be a good candidate for clinical studies and can in the future become an anthelmintic and antidermatophyte agent.

\section{Acknowledgements}

We are highly thankful to Sophisticated Analytical Instrumentation Laboratory, School of Pharmaceutical Sciences, Rajiv Gandhi Proudyogiki Vishwavidyalaya, Bhopal, Madhya Pradesh for spectral analysis and NRI Institute of Pharmacy, Bhopal, Madhya Pradesh (India) for providing necessary facilities to carry out the research work.

\section{References}

1. Fenical, W. Chemical Studies of Marine Bacteria: Developing a New Resource. Chem. Rev. 1993, 93, 1673-1683.

2. De Rosa, S.; Mitova, M.; Tommonaro, G. Marine Bacteria associated with Sponge as Source of Cyclic Peptides. Biomol. Eng. 2003, 20, 311-316.

3. Mitova, M.; Tommonaro, G.; De Rosa, S. A Novel Cyclopeptide from a Bacterium associated with the Marine Sponge Ircinia muscarum. Z. Naturforsch. C 2003, 58, 740-745.

4. Shin, J.; Seo, Y.; Lee, H.S.; Rho, J.R.; Mo, S.J. A New Cyclic Peptide from a Marine-derived Bacterium of the Genus Nocardiopsis. J. Nat. Prod. 2003, 66, 883-884.

5. Faulkner, D.J. Marine Natural Products. Nat. Prod. Rep. 1998, 15, 113-158. 
6. Mitova, M.; Popov, S.; De Rosa, S. Cyclic Peptides from a Ruegeria strain of Bacteria associated with the Sponge Suberites domuncula. J. Nat. Prod. 2004, 67, 1178-1181.

7. Cueto, M.; Jensen, P.R.; Fenical, W. N-Methylsansalvamide, a Cytotoxic Cyclic Depsipeptide from a Marine Fungus of the Genus Fusarium. Phytochemistry 2000, 55, 223-226.

8. Tan, L.T.; Cheng, X.C.; Jensen, P.R.; Fenical, W. Scytalidamides A and B, New Cytotoxic Cyclic Heptapeptides from a Marine Fungus of the Genus Scytalidium. J. Org. Chem. 2003, 68, 8767-8773.

9. Adachi, K.; Kanoh, K.; Wisespongp, P.; Nishijima, M.; Shizuri, Y. Clonostachysins A and B, New Anti-dinoflagellate Cyclic Peptides from a Marine-derived Fungus. J. Antibiot. 2005, $58,145-150$.

10. Lee, H.S.; Shin, H.J.; Jang, K.H.; Kim, T.S.; Oh, K.B.; Shin, J. Cyclic Peptides of the Nocardamine Class from a Marine-derived Bacterium of the Genus Streptomyces. J. Nat. Prod. 2005, 68, 623-625.

11. Rungprom, W.; Siwu, E.R.O.; Lambert, L.K.; Dechsakulwatana, C.; Barden, M.C.; Kokpol, U.; Blanchfield, J.T.; Kita, M.; Garson, M.J. Cyclic Tetrapeptides from Marine Bacteria associated with the Seaweed Diginea sp. and the Sponge Halisarca ectofibrosa. Tetrahedron 2008, 64, 3147-3152.

12. Dahiya, R.; Pathak, D. Cyclic Peptides: New Hope for Antifungal Therapy. Egypt. Pharm. J. (NRC) 2006, 5, 189-199.

13. Pathak, D.; Dahiya, R. Cyclic Peptides as Novel Antineoplastic Agents: A Review. J. Sci. Pharm. 2003, 4, 125-131.

14. Dahiya, R.; Pathak, D.; Himaja, M.; Bhatt, S. First Total Synthesis and Biological Screening of Hymenamide E. Acta Pharm. 2006, 56, 399-415.

15. Dahiya, R. Synthetic and Pharmacological Studies on Longicalycinin A. Pak. J. Pharm. Sci. 2007, 20, 317-323.

16. Dahiya, R. Synthetic Studies on a Cyclic Hexapeptide from Dianthus superbus. Chem. Pap. 2008, 62, 527-535.

17. Dahiya, R.; Kaur, K. Synthetic and Pharmacological Investigation of Segetalin C as a Novel Antifungal and Cytotoxic Agent. Arzneim. Forsch. 2008, 58, 29-34.

18. Dahiya, R.; Kumar, A.; Gupta, R. Synthesis, Cytotoxic and Antimicrobial Screening of a Proline-Rich Cyclopolypeptide. Chem. Pharm. Bull. 2009, 57, 214-217.

19. Dahiya, R.; Maheshwari, M.; Kumar, A. Toward the Synthesis and Biological Evaluation of Hirsutide. Monatsh. Chem. 2009, 140, 121-127.

20. Dahiya, R.; Gautam, H. Synthetic and Pharmacological Studies on a Natural Cyclopeptide from Gypsophila arabica. J. Med. Plants Res. 2010, 4, 1960-1966.

21. Dahiya, R.; Gautam, H. Total Synthesis and Antimicrobial Activity of a Natural Cycloheptapeptide of Marine-Origin. Mar. Drugs 2010, 8, 2384-2394.

22. Dahiya, R.; Gautam, H. Toward the First Total Synthesis of Gypsin D: A Natural Cyclopolypeptide from Gypsophila arabica. Am. J. Sci. Res. 2010, 11, 150-158.

23. Bodanzsky, M.; Bodanzsky, A. The Practice of Peptide Synthesis; Springer: New York, NY, USA, 1984; pp. 68-143. 
24. Garg, L.C.; Atal, C.K. Anthelmintic Activity of Myrsine africana. Indian J. Pharm. Sci. 1963, 59, 240-245.

25. Bauer, A.W.; Kirby, W.M.; Sherris, J.C.; Turck, M. Antibiotic Susceptibility Testing by a Standardized Single Disk Method. Am. J. Clin. Pathol. 1966, 45, 493-496.

Samples Availability: Available from the authors.

(C) 2010 by the authors; licensee MDPI, Basel, Switzerland. This article is an open access article distributed under the terms and conditions of the Creative Commons Attribution license (http://creativecommons.org/licenses/by/3.0/). 